\title{
Karakterisasi Senyawa Hasil Isolasi dari Ekstrak Etil Asetat Daun Namnam (Cynometra Cauliflora L.) yang Memiliki Aktivitas Antibakteri
}

\author{
Tiah Maharani, Dede Sukandar, Sandra Hermanto \\ Program Studi Kimia Fakultas Sains dan Teknologi UIN Syarif Hidayatullah Jakarta, \\ Jalan Ir. H. Juanda No 95 Ciputat 15412 Indonesia \\ Email: sukandarkimia@uinjkt.ac.id
}

Received: April 2016; Revised: Mei 2016; Accepted: Mei 2016; Available Online: Mei 2016

\begin{abstract}
Abstrak
Namnam dikenal sebagai tanaman famili fabacea yang banyak mengandung senyawa fenolik dengan beragam aktivitas biologis diantaranya antibakteri. Penelitian ini bertujuan mengisolasi dan mengkarakterisasi senyawa aktif antibakteri hasil isolasi dari ekstrak etil asetat daun namanam (Cynometra cauliflora L.). Ekstraksi dilakukan dengan cara maserasi, fraksinasi dengan kromatografi kolom, uji antibakteri dengan metode difusi cakram, dan karakterisasi senyawa dengan spektroskopi UV-Vis, FTIR dan LCMS. Ekstrak etil asetat memiliki aktivitas antibakteri dengan zona hambat masing-masing 12,25 dan 6,00 mm terhadap Escherecia coli dan Stapilococcus aureus pada konsentrasi 100.000 ppm. Hasil kromatografi kolom fraksi 23-30 menghasilkan tiga isolat dengan $\operatorname{Rf} 0,20 \mathrm{~cm} ; 0,33 \mathrm{~cm}$ dan $0,87 \mathrm{~cm}$. Karakteristik senyawa aktif antibakteri pada isolat ke-2 (Rf 0,33 $\mathrm{cm}$ ) berdasarkan hasil analisa UV-Vis terdapat serapan pada $\lambda_{\text {maks }} 206,93 \mathrm{~nm}, 268,40 \mathrm{~nm}, 328,58 \mathrm{~nm}, 383,98 \mathrm{~nm}$ dan $386,98 \mathrm{~nm}$, FTIR (KBr) menunjukkan adannya gugus $-\mathrm{OH} 3415,68 \mathrm{~cm}^{-1}, \mathrm{C}-\mathrm{H} 2958,10 \mathrm{~cm}^{-1}, \mathrm{C}=\mathrm{C}$ aromatik $1651,18 \mathrm{~cm}^{-1}$, C-OH siklik $1019,88 \mathrm{~cm}^{-1}$ dan $\mathrm{CH}$ aromatik $694,56 \mathrm{~cm}^{-1}$ dan LCMS menghasilkan 3 puncak utama pada waktu retensi 4,82; 6,87 dan 7,64 yang diduga merupakan senyawa 2-isopropil-5-metilsikloheksil 2hidroksipropanoat, Cuelure, dan 2-[(2-Hydroxycyclohexyl)oxy] cyclohexanecarboxylate.
\end{abstract}

Kata kunci: antibakteri, difusi cakram, namnam (Cynometra cauliflora L.).

\begin{abstract}
Namnam is known as a plant family of fabacea that contains phenolic compounds with diverse biological activities including antibacterial. The aim of this study was to isolate and characterize the antibacterial activity of compounds isolated from ethyl acetate extract of the leaves namanam (Cynometra cauliflora L.). Extraction was done by maceration, fractionation by column chromatography, antibacterial essay by disc diffusion method, and characterization of compounds with UV-Vis, FTIR spectroscopy and LCMS. Ethyl acetate extracts have antibacterial activity with inhibition zone respectively 12.25 and $6.00 \mathrm{~mm}$ to Escherecia coli and Stapilococcus aureus at a concentration of 100,000 ppm. The results of column chromatography fractions 23-30 yielded three isolates with Rf $0.20 \mathrm{~cm} ; 0.33 \mathrm{~cm}$ and $0.87 \mathrm{~cm}$. Characteristics of antibacterial active compounds in isolates 2 (Rf $0.33 \mathrm{~cm}$ ) is based on the analysis results are UV-Vis absorption at $\lambda$ maks $206.93 \mathrm{~nm}, 268.40 \mathrm{~nm}, 328.58 \mathrm{~nm}$, $383.98 \mathrm{~nm}$ and $386.98 \mathrm{~nm}$, FTIR (KBr) showed -OH group $3415.68 \mathrm{~cm}^{-1}, \mathrm{CH} 2958.10 \mathrm{~cm}^{-1}, \mathrm{C}=\mathrm{C}$ aromatic $1651.18 \mathrm{~cm}^{-1}, \mathrm{C}-\mathrm{OH}$ cyclic $1019.88 \mathrm{~cm}^{-1}$ and $\mathrm{CH}$ aromatic $694.56 \mathrm{~cm}^{-1}$ and LCMS produce three main peak at a retention time of $4.82 ; 6.87$ and 7.64 which is thought to be the compound 2-isopropyl-5-metilsikloheksil 2hidroksipropanoat, Cuelure, and 2-[(2-Hydroxycyclohexyl) oxy] cyclohexanecarboxylate.
\end{abstract}

Key word: antibacterial, disc diffusion, Namnam (Cynometracauliflora L.).

DOI: $h t t p: / / d x . d o i . o r g / 10.15408 / j k v . v 2 i 1.3084$ 


\section{PENDAHULUAN}

Indonesia memiliki sumber daya alam hayati yang sangat beranekaragam dan merupakan sumber senyawa kimia yang tak terbatas jenis dan jumlahnya. Keanekaragaman hayati dapat diartikan sebagai keanekaragaman kimiawi yang menghasilkan bahan-bahan kimia untuk kebutuhan manusia seperti obatobatan, insektisida, kosmetika, dan sebagai bahan dasar sintesa senyawa organik yang lebih bermanfaat (Lenny, 2006).

Salah satu jenis tanaman yang dapat dijadikaan sebagai obat alami adalah namnam. Tanaman namnam (C.cauliflora L.) merupakan satu diantara jenis keanekaragaman sumber daya hayati di Indonesia. Tanaman ini hampir tersebar di seluruh Asia Tenggara dan termasuk ke dalam golongan tanaman langka karena mulai sulit ditemukan dan hanya ditemukan di beberapa daerah (Ikram et al., 2009). Tanaman namnam dapat dipakai sebagai tanaman penghias halaman atau untuk diambil buahnya. Buah yang masak berasa asam manis segar dan dapat dimakan langsung atau sebagai bahan rujak, asinan, manisan maupun campuran sambal (Hyne, 1987).

Antibakteri adalah zat yang menghambat pertumbuhan bakteri dan digunakan secara khusus untuk mengobati infeksi. Aktivitas suatu zat yang bersifat antibakteri dipengaruhi oleh beberapa faktor penting seperti konsentrasi bahan, $\mathrm{pH}$, komposisi medium, suhu, jenis bakteri penguji dan kemampuan antibakteri untuk mengurangi dalam medium. Cara kerja antibakteri menurut Pelczar dan Chan (1998) antara lain merusak dinding sel, merubah permeabilitas sel, menghambat sintesis protein dan asam nukleat, dan menghambat kerja enzim.

Berdasarkan penelitian Cahyaningtyas (2014), fraksi etil asetat dari buah namnam memiliki aktivitas antibakteri tertinggi pada konsentrasi $90 \%$ dengan zona hambat sebesar $11.5 \mathrm{~mm}$ terhadap bakteri $E$. coli dan $11 \mathrm{~mm}$ terhadap bakteri $S$. aureus. Berdasarkan analisa GCMS terhadap ekstrak etil asetat, diketahui bahwa senyawa aktif yang bersifat antibakteri diduga memiliki kemiripan dengan eukaliptol, $\beta$-fenil alkohol, 2-amino-4,5-dihidro-5-metil tiazol dan di-(2-etileksil) ftalat.

Namun demikian penelitian mengenai antibakteri dari daun namnam belum banyak dilakukan. Berdasarkan latar belakang tersebut diperlukan adanya eksplorasi penelitian aktivitas antibakteri daun namnam terhadap $E$. coli dan $S$. aureus dengan metode difusi dan karakterisasi senyawa aktif antibakteri menggunakan UV-Vis, FTIR dan LCMS.

\section{METODE PENELITIAN}

\section{Alat dan Bahan}

Alat yang digunakan dalam penelitian ini adalah alat-alat gelas, cawan petri, jarum ose, ketas cakram, alumunim foil, pipet mikro, vortex, neraca analitik, rotary evaporator Heidolph, autoklaf Tommy, Spektrofotometer UV-Vis Tipe Lamda 25 Perkin Elmer, Spektrofotometer FTIR Spectrum One Perkin Elmer, dan Spektrofotometer LCMS QTOF merk XEVO G2 S.

Bahan yang digunakan dalam penelitian ini adalah sampel daun namnam yang berasal dari desa Cintaratu Kecamatan Parigi Kabupaten Pangandaran Jawa Barat, metanol, n-heksana, etil asetat, kloroform, plat silika kieselgel $\mathrm{F}_{254}$ silika $\mathrm{G} 70$ (2300-400 mesh) Merck, aquades, media Nutrient Agar (NA), Nutrient Broth (NB), etanol, kertas whatmann no.41 serta biakan E. coli ATCC 25922 dan $S$. aureus ATCC 25923 yang berasaldari Laboratorium Mikrobiologi Universtas Indonesia. Kontrol positif yang digunakan adalah penicilin dan amoxycilin.

\section{Ekstraksi}

Serbuk daun namnam (C. cauliflora L.) sebanyak $1.5 \mathrm{Kg}$ yang telah dikeringkan dimaserasi dengan metanol selama $3 \times 24$ jam. Kemudian seluruh ekstrak cair metanol disaring dan diuapkan menggunakan rotary evaporator pada suhu $40-50{ }^{\circ} \mathrm{C}$ hingga metanol menguap seluruhnya dan menjadi ekstrak kental. Ekstrak kental metanol dipartisi menggunakan pelarut yang semakin meningkat kepolarannya dari pelarut nonpolar sampai polar yaitu n-heksana, etil asetat dan methanol hingga terbentuk 2 fase dan dipisahkan. Partisi dilakukan berulang hingga fase metanol yang berada di atas jernih.

\section{Uji Antibakteri}

Sterilisasi alat dilakukan sebelum semua peralatan digunakan dengan autoklaf pada 121 ${ }^{0} \mathrm{C}$ dengan tekanan 15 psi selama 15 menit (Irianto, 2006). Alat-alat yang tidak tahan terhadap panas tinggi disterilkan dengan alkohol $70 \%$.

Sebanyak 3 gram Nutrien Agar (NA) dilarutkan dalam $300 \mathrm{~mL}$ aquades sebagai media dipanaskan dan disterilisasi, kemudian, 
media untuk peremajaan diletakkan dalam keadaan miring pada suhu ruang selama 24 jam (Harmita et al., 2005). Media cair (Nutrient Broth) dibuat sebanyak 0.24 gram Nutrient Broth (NB) dilarutkan dalam $30 \mathrm{~mL}$ akuades sebagai media tumbuh bakteri, kemudian dipanaskan dan disterilisasi. Biakan murni bakteri diremajakan pada media padat agar miring dengan cara menggoreskan jarum ose yang mengandung bakteri $S$. aureus dan bakteri $E$. coli secara aseptis dan diinkubasi selama 24 jam pada suhu $37{ }^{0} \mathrm{C}$ dalam inkubator.

Media padat yang telah dipanaskan hingga mencair, didinginkan sampai suhu 40 ${ }^{0} \mathrm{C}$ kemudian ditambahkan $0.2 \mathrm{~mL}$ larutan biakan aktif, dihomogenkan hingga merata kemudian dituangkan ke dalam cawan petri steril dan dibiarkan hingga memadat. Kertas cakram (diameter $6 \mathrm{~mm}$ ) diresapkan dalam ekstrak dan kontrol. Proses peresapan dilakukan dengan cara kertas cakram dicelupkan ke dalam larutan kontrol negatif (pelarut), kontrol positif (penicilin dan amoxicilin), dan larutan ekstrak etil asetat, dan larutan ekstrak (konsentrasi 20000 ppm, 40000 ppm, 60000 ppm, 80000 ppm dan 100000 ppm). Setelah dicelup, kertas cakram didiamkan beberapa saat di dalam cawan petri kosong steril. Kertas cakram selanjutnya diletakkan di atas permukaan media bakteri menggunakan pinset dan ditekan sedikit. Selanjutnya, diinkubasi pada suhu $37{ }^{0} \mathrm{C}$ selama 24 jam. kemudian, diukur zona hambatnya dengan menggunakan penggaris dengan mengukur tepi ke tepi seberang zona hambat pada cakram (Harmita, 2005).

\section{Kromatografi Kolom dan KLT}

Ekstrak yang dikolom adalah ekstrak etil asetat, dipilihnya ekstrak etil asetat dikarenakan memiliki kandungan senyawa yang lebih besar dibandingan ekstrak lainnya. Kolom yang digunakan adalah kolom kering dan untuk sampel digunakan cara kering., kemudian dibuat sebagai larutan uji yang akan dipisahkan dengan TLC dan kromatografi kolom dengan fase diam berupa silika $\mathrm{F}_{254}$ dan silika gel (70-230 mesh) Merck secara berturut-turut. Bercak diamati dibawah sinar UV $365 \mathrm{~nm}$. Setiap hasil fraksi yang memberikan nilai $\mathrm{Rf}$ yang sama kemudian disatukan dan diuapkan untuk dilakukan pengujian lebih lanjut.

\section{Analisis UV-Vis}

Sampel dikerok kemudian dilarutkan pada $5 \mathrm{~mL}$ metanol.Larutan tersebut divorteks selama 5 menit kemudian didiamkan selama 1 jam, agar senyawa pada silika larut ke dalam pelarut. Sampel kemudian disaring lalu diuji pada spektro UV-VIS dengan panjang gelombang 200-400 nm.

\section{Analisis FTIR}

Sebanyak $1 \mathrm{mg}$ sampel digerus dengan $100 \mathrm{mg} \mathrm{KBr}$ secara homogen, kemudian diukur serapan infra merahpada bilangan gelombang $4000-450 \mathrm{~cm}^{-1}$ dan dianalisa lebih lanjut.

\section{Analisis LCMS}

Sebanyak $1 \mathrm{mg}$ senyawa ditimbang dan dilarutkan dalam metanol. Diambil $10 \mu \mathrm{L}$ sampel dan disuntikkan pada LCMS/MS melalui kolom C-18 (2 x $150 \mathrm{~mm})$ dengan kecepatan alir $0.3 \mathrm{~mL} / \mathrm{menit}$.

\section{HASIL DAN PEMBAHASAN}

Ekstrak kental daun namnam yang dihasilkan melalui metode maserasi dengan pelarut metanol dari $1.5 \mathrm{~kg}$ daun namnam kering sebanyak 99.07 gram dengan persen rendemen $6.6 \%$. sedangkan persen rendemen ekstrak hasil partisi n-heksana, etil asetat, meatanol-air secara berturut-turut sebesar $25.87 \%, \quad 18.8 \%, \quad 38.94 \%$. Hasil analisis fitokimia terhadap ektrak n-heksan, ekstrak etil asetat dan ekstrak metanol-air yang paling banyak mengandung senyawa metabolit sekunder adalah ekstrak etil asetat yaitu alkaloid, flavonoid, tannin, terpenoid dan kuinon.

Uji aktivitas antibakteri dilakukan terhadap bakteri $S$. aureus dan $E$. coli menggunakan metode difusi cakram, dimana senyawa aktif akan berdifusi dengan media dan bakteri uji. Aktivitas antibakteri dapat dilihat dengan ada tidaknya diameter zona bening di sekitar cakram. Diameter zona bening disekitar cakram yang berisi ekstrak yang diuji diukur dan dibandingkan dengan diameter zona bening di sekitar cakram yang berisi kontrol positif (penisilin dan amoksilin) dan kontrol negatif (pelarut metanol, heksana dan etil asetat). Aktivitas antibakteri dilakukan terhadap ekstrak etil asetat, n-heksan, dan metanol-air diuji terhadap bakteri $E$. coli dan $S$. aureus. 
Ekstrak etil asetat memiliki diameter zona hambat yang lebih luas daripada ekstrak metanol:air dan ekstrak n-heksana untuk perlakuan pada bakteri $S$. aureus sedangkan untuk bakteri $E$. coli diameter zona hambat ketiga ekstrak memiliki nilai yang sama. Data hasil pengujian dapat dilihat pada Tabel 1 .

Apabila hasil analisis (Tabel 1 dan Tabel 2) dikaitkan dengan ketentuan kekuatan antibakteri yang dikemukakan oleh Davis dan Stout (1971), maka kekuatan antibakteri yang terkandung dalam ekstrak etil asetat, metanol dan n-heksana masuk dalam kategori sedang (masuk dalam kisaran 5-10 mm), hal ini diduga karena kandungan senyawa yang berpotensi sebagai antibakteri pada ekstrak tersebut sudah cukup banyak, sehingga cukup mampu untuk menghambat pertumbuhan bakteri.

Ekstrak etil asetat memiliki penghambatan tertinggi pada bakteri $S$. aureus sebesar $12.25 \pm 0.35 \mathrm{~mm}$. Ini menunjukan bahwa ekstrak etil asetat merupakan ekstrak aktif dibandingkan $n$-heksana dan metanol. Hasil uji untuk kontrol negatif, menunjukkan tidak adanya zona hambat yang terbentuk. Diameter hambat yang dihasilkan pada bakteri $S$. aureus lebih besar dibandingkan dengan bakteri $E$. coli disebabkan adanya perbedaan dinding sel bakteri Gram positif dan gram negatif yang mempengaruhi besarnya aktivitas antibakteri. Dinding sel bakteri Gram negatif lebih kompleks dibandingkan dengan bakteri Gram positif. Bakteri Gram negatif memiliki lapisan membran luar yang meliputi peptidoglikan. Adanya membran ini menyebabkan dinding sel bakteri Gram negatif memiliki lapisan lipopolisakarida yang berfungsi sebagai penghalang masuknya beberapa macam substansi termasuk antibiotik (Tjitrosono,1986).

Tabel 1. Hasil uji aktivitas antibakteri terhadap bakteri S.aureus dan E.coli

\begin{tabular}{|c|c|c|c|c|c|c|c|c|c|}
\hline \multirow{4}{*}{$\begin{array}{l}\text { Konsentrasi } \\
\text { (ppm) }\end{array}$} & \multicolumn{9}{|c|}{ S. aureus } \\
\hline & \multirow{2}{*}{\multicolumn{2}{|c|}{$\begin{array}{l}\text { Etil Asetat } \\
\text { Diameter } \\
(\mathrm{mm})\end{array}$}} & \multirow{3}{*}{ Rata-rata } & \multirow{2}{*}{\multicolumn{2}{|c|}{$\begin{array}{l}\text { Metanol } \\
\text { Diameter } \\
(\mathrm{mm})\end{array}$}} & \multirow{3}{*}{ Rata-rata } & \multirow{2}{*}{\multicolumn{2}{|c|}{$\begin{array}{l}n \text {-Heksana } \\
\text { Diameter } \\
(\mathrm{mm})\end{array}$}} & \multirow{3}{*}{ Rata-rata } \\
\hline & & & & & & & & & \\
\hline & 1 & 2 & & 1 & 2 & & 1 & 2 & \\
\hline 20000 & 11 & 12 & $11.5 \pm 0.71$ & 6 & 6 & $6 \pm 0$ & 6 & 6 & $6 \pm 0$ \\
\hline 40000 & 10.25 & 10.7 & $10.45 \pm 0.32$ & 6 & 6 & $6 \pm 0$ & 6 & 6 & $6 \pm 0$ \\
\hline 60000 & 9.75 & 9.5 & $9.625 \pm 0.18$ & 6 & 6 & $6 \pm 0$ & 6 & 6 & $6 \pm 0$ \\
\hline 80000 & 10 & 9.5 & $9.75 \pm 0.35$ & 6 & 6 & $6 \pm 0$ & 6 & 6 & $6 \pm 0$ \\
\hline 100000 & 12.5 & 12 & $12.25 \pm 0.35$ & 6 & 6 & $6 \pm 0$ & 6 & 6 & $6 \pm 0$ \\
\hline Penisilin & 35 & 35 & $35 \pm 0$ & 30.5 & 31 & $30.75 \pm 0.35$ & 31 & 30.5 & $30.75 \pm 0.35$ \\
\hline Amoksilin & 20 & 20 & $20 \pm 0$ & 19 & 18.5 & $18.75 \pm 0.35$ & 19.5 & 19.5 & $19.5 \pm 0$ \\
\hline $\begin{array}{l}\text { Kontrol } \\
\text { negatif }\end{array}$ & - & - & - & - & - & - & - & . & 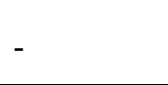 \\
\hline
\end{tabular}

Tabel 2. Hasil Uji Aktivitas Antibakteri Terhadap bakteri S.aureus dan E.coli

\begin{tabular}{|c|c|c|c|c|c|c|c|c|c|}
\hline \multirow[t]{2}{*}{$\begin{array}{l}\text { Konsentrasi } \\
(\mathrm{ppm})\end{array}$} & \multicolumn{2}{|c|}{$\begin{array}{l}\text { Etil Asetat } \\
\text { Diameter } \\
(\mathrm{mm})\end{array}$} & \multirow[t]{2}{*}{ Rata-rata } & \multicolumn{2}{|c|}{$\begin{array}{l}\text { Metanol } \\
\text { Diameter } \\
(\mathrm{mm})\end{array}$} & \multirow[t]{2}{*}{ Rata-rata } & \multicolumn{2}{|c|}{$\begin{array}{l}n \text {-Heksana } \\
\text { Diameter } \\
(\mathrm{mm})\end{array}$} & \multirow[t]{2}{*}{ Rata-rata } \\
\hline & 1 & 2 & & 1 & 2 & & 1 & 2 & \\
\hline 20000 & 6 & 6 & 6 & 6 & 6 & 6 & 6 & 6 & 6 \\
\hline 40000 & 6 & 6 & 6 & 6 & 6 & 6 & 6 & 6 & 6 \\
\hline 60000 & 6 & 6 & 6 & 6 & 6 & 6 & 6 & 6 & 6 \\
\hline 80000 & 6 & 6 & 6 & 6 & 6 & 6 & 6 & 6 & 6 \\
\hline 100000 & 6 & 6 & 6 & 6 & 6 & 6 & 6 & 6 & 6 \\
\hline Penisilin & 6 & 6 & 6 & 6 & 6 & 6 & 6 & 6 & 6 \\
\hline Amoksilin & 11 & 11 & 11 & 11 & 11 & 11 & 11 & 11 & 11 \\
\hline $\begin{array}{l}\text { Kontrol } \\
\text { negatif }\end{array}$ & - & - & - & - & - & - & - & - & - \\
\hline
\end{tabular}


Pelczar dan Chan (1988) menjelaskan bahwa kerja senyawa yang bersifat antibakteri terdapat beberapa mekanisme. Mori et al., (1987) melaporkan bahwa senyawa flavonoid dapat menghambat sintesis asam nukleat, cincin B dari flavonoid berinterlokasi atau ikatan hidrogen pada cincin B berikatan dengan basa pada asam nukleat sehingga dapat menghambat sintesis DNA dan RNA.

Tanin dapat menghambat $S$. aureus melalui reaksi enzimatis dengan menghambat struktur membran plasma dengan nilai MIC $100 \mathrm{mg} / \mathrm{L}$. Kondisi aerobik dalam pertumbuhan bakteri membutuhkan Fe untuk reduksi ribonukleotida. Namun, kehadiran tanin dapat mengkelat $\mathrm{Fe}$ sehingga fungsi tersebut dapat terganggu dan menyebabkan sel bakteri mengalami kematian (Akiyama et al., 2001).

Hasil analisa spektroskopi UV-Vis menggunakan pelarut metanol dengan rentang panjang gelombang 200-700 nm (Gambar 1). Berdasarkan hasil pengukuran didapatkan beberapa puncak panjang gelombang maksimum. Panjang gelombang maksimum $206.93 \mathrm{~nm}$ dan $268.40 \mathrm{~nm}$ merupakan transisi elektron dari $\pi \rightarrow \pi^{*}$ ikatan rangkap dan panjang gelombang maksimum untuk 328.56 $\mathrm{nm} ; 383.98 \mathrm{~nm}$ dan $386.31 \mathrm{~nm}$ merupakan transisi elektron $\mathrm{n} \rightarrow \pi^{*}$ gugus karbonil (Supratman, 2010).

Hasil analisa menggunakan FTIR menunjukan bahwa isolat etil asetat memiliki serapan beberapa gugus fungsi, spektrum IR isolat ditunjukkan pada Gambar 2. Hasil spektroskopi IR isolat 1 menunjukkan adanya gugus fungsional suatu senyawa berdasarkan serapan spektrum elektromagnetik pada daerah IR, diantaranya bilangan gelombang 3415.68 $\mathrm{cm}^{-1}$ yang menunjukan adanya gugus fenol dengan gugus $\mathrm{O}-\mathrm{H}\left(3200-3600 \mathrm{~cm}^{-1}\right)$ dugaan ini diperkuat adanya serapan pada bilangan gelombang 2958.10 yang merupakan gugus $\mathrm{CH}$ alifatik $\left(2850-2970 \mathrm{~cm}^{-1}\right)$ dan bilangan gelombang $1019.88 \mathrm{~cm}^{-1}$ adalah gugus $\mathrm{C}-\mathrm{OH}$ siklik (990-1060 $\left.\mathrm{cm}^{-1}\right)$ (Silverstain et al., 2005). Serapan pada bilangan gelombang $1651.18 \mathrm{~cm}^{-1}$ ditimbulkan oleh gugus $\mathrm{C}=\mathrm{C}$ (1620-1680 $\left.\mathrm{cm}^{-1}\right)$ dan bilangan gelombang $694.56 \mathrm{~cm}^{-1}\left(690-900 \mathrm{~cm}^{-1}\right)$ yang merupakan gugus dari $\mathrm{CH}$ aromatik (Suradikusumah, 2005).

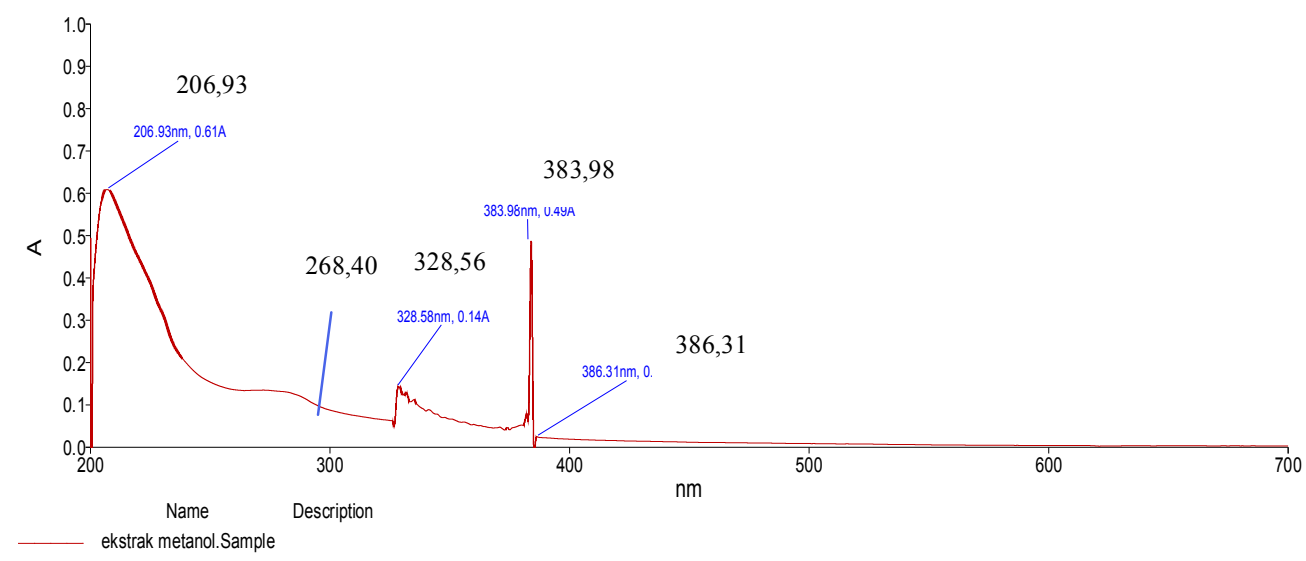

Gambar 1. Hasil analisa isolat dengan spektrofotometer UV-Vis

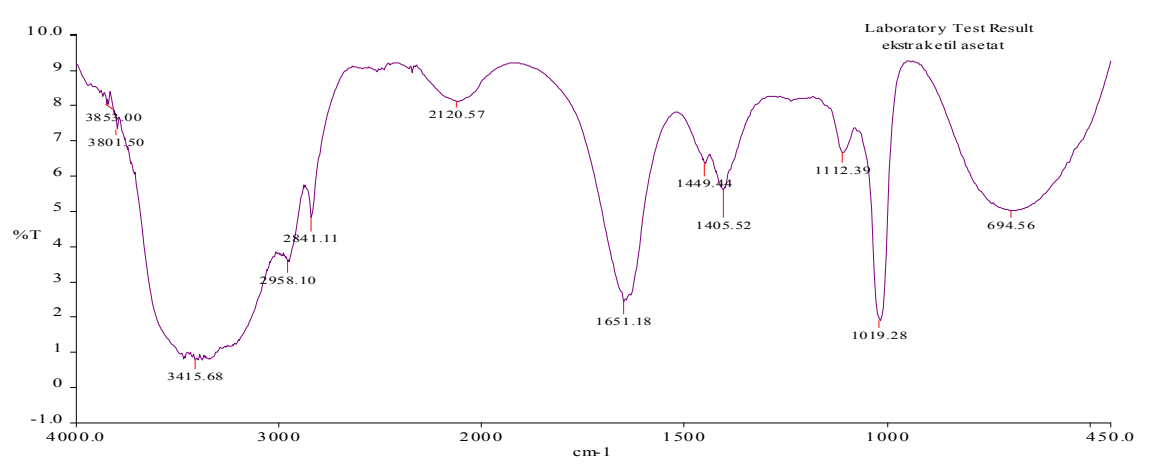

Gambar 2. Hasil analisa isolat dengan spektrofotometer IR 
Analisis hasil spektroskopi IR tersebut menunjukkan bahwa senyawa yang diisolasi kemungkinan mempunyai gugus fungsi $-\mathrm{OH}$, $\mathrm{C}-\mathrm{H}, \mathrm{C}=\mathrm{C}$ aromatik, $\mathrm{C}-\mathrm{OH}$ siklik dan $\mathrm{CH}$ aromatik. Berdasarkan interpretasi data yang diperoleh dari analisa spektrum UV-Vis dan spektrum inframerah (IR) maka diduga bahwa isolat pada ekstrak fraki etil asetat mengandung senyawa fenolik.

Hasil analisa menggnakan LCMS menghasilkan beberapa puncak kromatogram dengan waktu retensi yang sesuai pada Gambar 3. Hasil spektrum diatas menunjukkan bahwa isolat etil asetat belum murni. Berdasarkan puncak-puncak tersebut diperoleh delapan puncak pada waktu retensi $4.82 ; 5.42 ; 5.85$;
$6.87 ; 7.15 ; 7.64 ; 8.42$ dan 9.05 menit. Sedikitnya terdapat tiga puncak utama pada waktu retensi 4.82; 6.87 dan 7.64 yang akan diidentifikasikan senyawanya berdasarkan spektrum massanya. Analisis data LCMS ini menggunakan MassLynx software (Version 4.1) dan identifikasi struktur senyawa kimia yang terdeteksi pada LCMS dengan database Massbank dan Chemspider secara online.

Puncak utama dari spektrum massa isolat 1 pada waktu retensi 4.28 menit memiliki berat molekul 228.1427 dengan dugaan rumus molekul senyawa $\mathrm{C}_{13} \mathrm{H}_{24} \mathrm{O}_{3}$ yang diperkirakan merupakan senyawa 2-isopropil-5metilsikloheksil 2- hidroksipropanoat (Over et al., 2012).

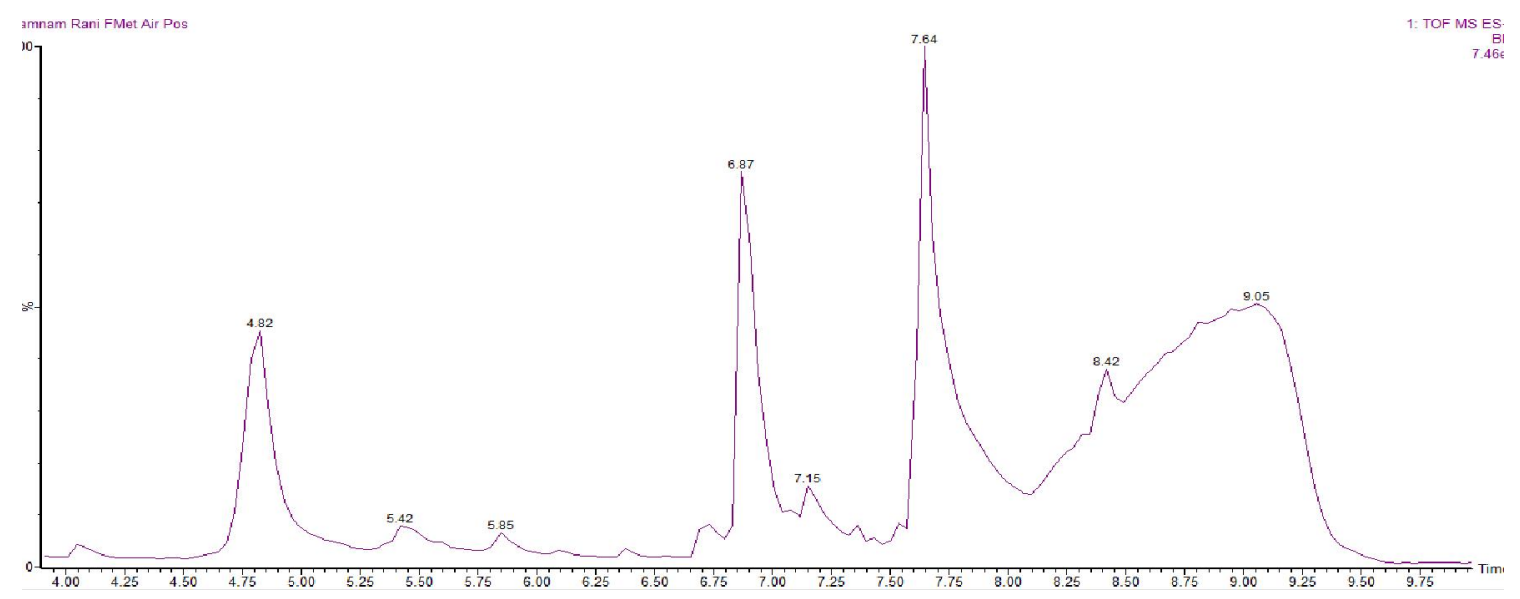

Gambar 3. Spektrum kromatogram LCMS

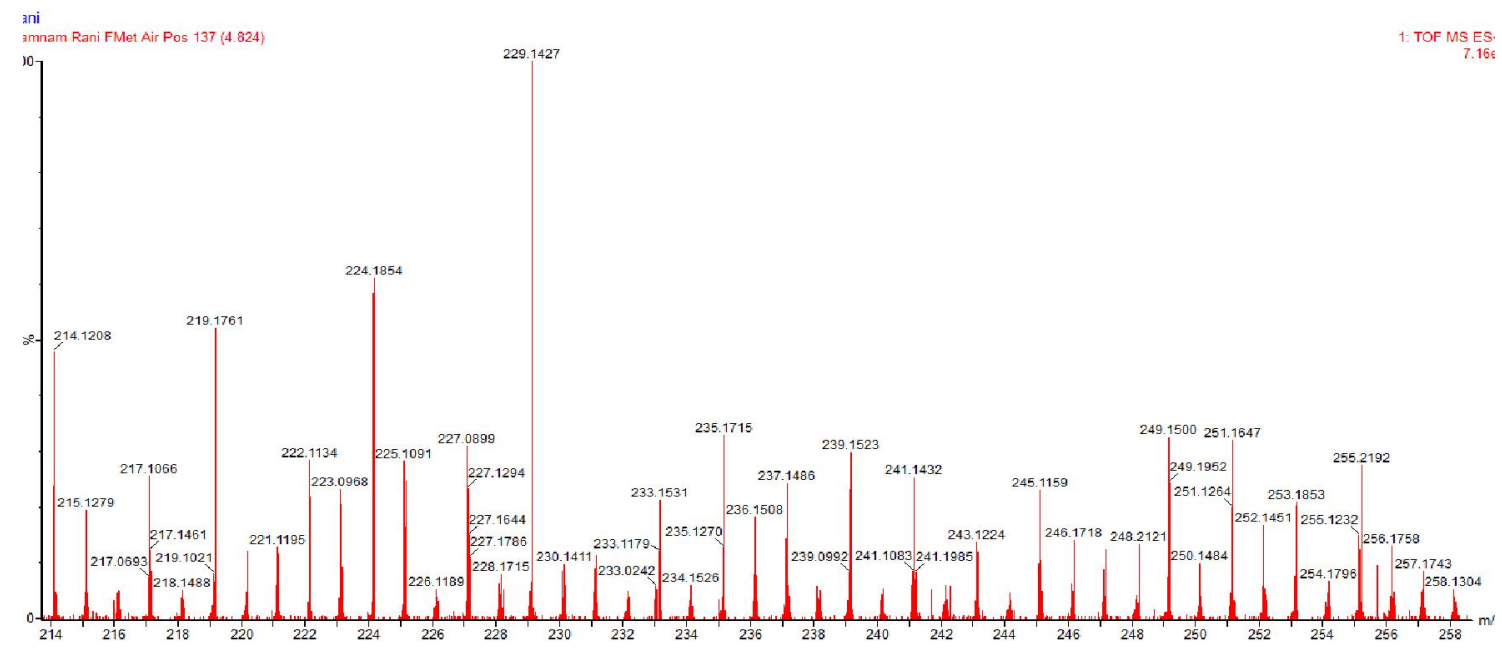

Gambar 4. Spektrum massa senyawa pada Rt 4.28 


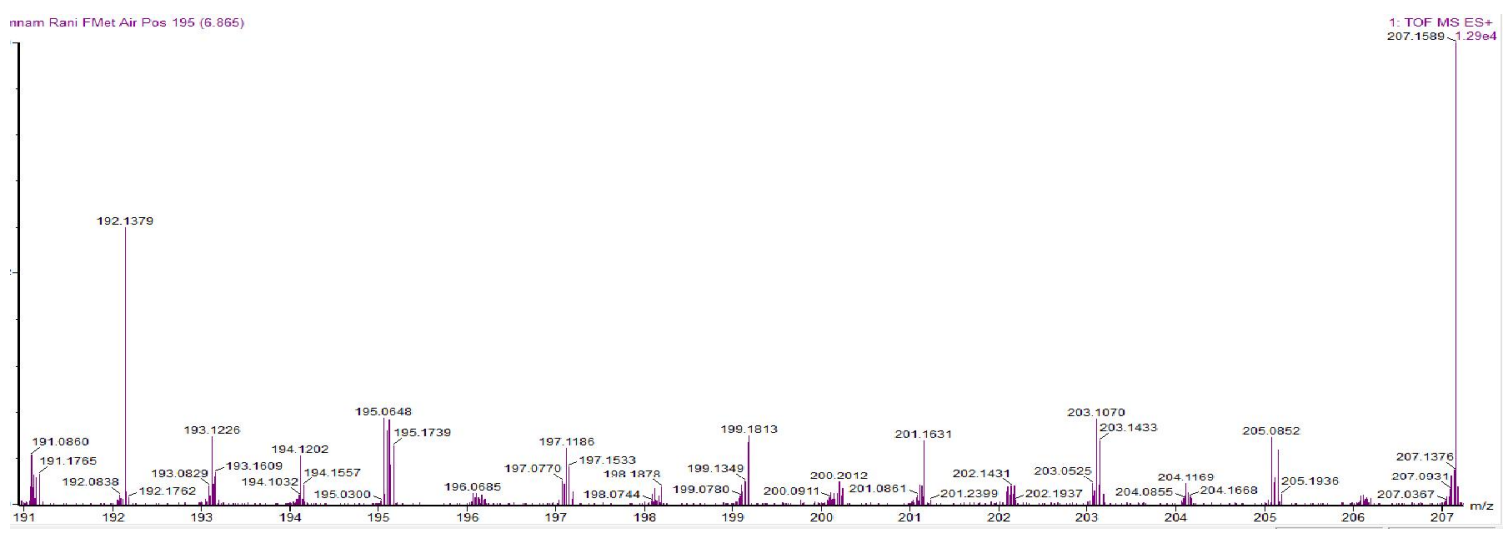

Gambar 5. Spektrum massa senyawa pada Rt 6.87

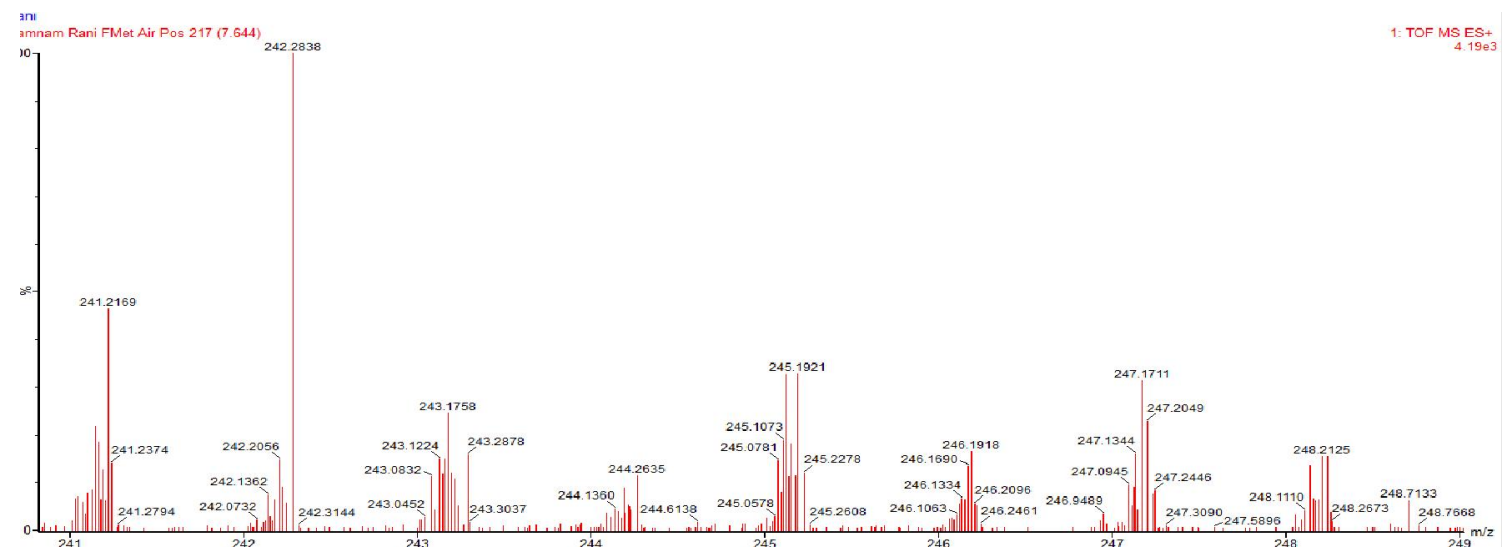

Gambar 6. Spektrum massa senyawa pada Rt 7.64

Spektrum massa senyawa pada waktu retensi 6.87 menit terlihat pada Gambar 5 . Puncak utama senyawa pada waktu retensi 6.87 menit memiliki berat molekul 206.1589 dengan dugaan rumus molekul $\mathrm{C}_{12} \mathrm{H}_{14} \mathrm{O}_{3}$ dan diperkirakan senyawa Cuelure (Michael et al, 1990). Spektrum massa senyawa pada waktu retensi 7.64 menit terlihat pada Gambar 28. Puncak utama senyawa pada waktu retensi 7.64 menit memiliki berat molekul 242.2838 dengan dugaan rumus molekul $\mathrm{C}_{13} \mathrm{H}_{21} \mathrm{O}_{4}$ yang diperkirakan merupakan senyawa 2-[(2Hydroxycyclohexyl)oxy]

cyclohexanecarboxylate (Prathipati et al., 2008).

Berdasarkan hasil analisa LCMS yang dilakukan, dugaan senyawa yang didapatkan tidak memiliki aktivitas antibakteri. Penelitian yang telah dilakukan Michael et al (1990), melaporkan bahwa cuelure merupakan senyawa yang terdapat di dalam kelenjar sekresi lalat buah (Dacus nigrotibialis). Over et al,. (2012) melaporkan bahwa 2-isopropil-5metilsikloheksil 2- hidroksipropanoat merupakan fragmen berbasis penemuan ligan dari turunan produk bahan alam. Prathipati et al (2008) melaporkan senyawa 2-[(2Hydroxycyclohexyl)oxy] cyclohexanecarboxylat $e$ merupakan agen antituberkulosis berdasarkan Models Bayesians.

Senyawa yang memiliki kandungan sebagai antibakteri satu diantaranya adalah flavonoid, Mori et al., (1987) melaporkan ada beberapa senyawa flavonoid yang mengandung antibakteri, diantaranya 7,8-dihidroksiflavon, Daticetin, Robinetin, Myricetin, dan Epigallocatechin. Shinta (2002) melaporkan daun sirih memiliki senyawa fenilpropanoid sebagai antibakteri dengan senyawa asam 3,5dimetoksi-2-hidroksi-etilsinamat. 


\section{SIMPULAN}

Ekstrak etil asetat daun namnam (Cynometra cauliflora L.) memiliki aktivitas antibakteri dengan zona hambat sebesar 12.25 $\mathrm{mm}$ terhadap bakteri S.aureus dan $6 \mathrm{~mm}$ terhadap bakteri E.coli pada konsentrasi 100.000 ppm.

Senyawa aktif antibakteri dari isolat ekstrak etil asetat daun namnam memiliki serapan ultraviolet pada $\lambda_{\text {maks }} 206.93 \mathrm{~nm}$, $268.40 \mathrm{~nm}, 328.58 \mathrm{~nm}, 383.98 \mathrm{~nm}$ dan 386.98 $\mathrm{nm}$, memiliki gugus fungsi pada bilangan gelombang $3415.68 \mathrm{~cm}^{-1}$ (OH fenol), 2958.10 $\mathrm{cm}^{-1}(\mathrm{CH}), \quad 1019.88 \mathrm{~cm}^{-1} \quad(\mathrm{C}-\mathrm{OH}$ siklik), $1651.18 \mathrm{~cm}^{-1}\left(\mathrm{C}=\mathrm{C}\right.$ aromatik) dan $694.56 \mathrm{~cm}^{-1}$ (CH aromatik), dan menghasilkan 3 puncak utama pada waktu retensi 4.82; 6.87 dan 7.64 yang diduga senyawa 2-isopropil-5metilsikloheksil 2-hidroksipropanoat, Cuelure, dan 2-[(2-Hydroxycyclohexyl)oxy] cyclohexanecarboxylate.

\section{SARAN}

Perlu dilakukan pemurnian sampel kembali dengan cara kromatografi kolom agar diperoleh senyawa murni lalu diuji aktivitas antibakterinya dan ditentukan struktur molekulnya menggunakan spektrofotometri UV-Vis, FTIR, MS dan NMR. Serta perlu dilakukan penelitian lebih lanjut mengenai potensi bioaktivitas lainnya selain antibakteri.

\section{DAFTAR PUSTAKA}

Akiyama H, Kazuyasu F, Osamu Y, Takashi O, Keiji I. 2001. Antibacterial Action of Several Tannins Against Staphylococcus aureus. Journal of antimicrobial Chemotherapy. 48: 487-491.

Cahyaningtyas G. 2014. Karakteristik Senyawa Aktif Antibakteri dari Ekstrak Metanol Buah Namnam (Cynometra cauliflora L.). Skripsi, Universitas Islam Negeri Syarif Hidayatullah Jakarta.

Davis WW, TR Stout. 1971. Disc Plate Methods of Microbiological Antibiotic Assay. Microbiology 22: 659-665.

Harmita, Radji M, Biomed M. 2005. Buku Ajar Analisis Hayati. Edisi kedua. Departemen
Farmasi MIPA Universitas Indonesia, Depok.

Heyne K. 1987. Tumbuhan Berguna Indonesia, Jilid 1. Yayasan Sarana Wana Jaya, Jakarta.

Ikram EHK, Eng KH, Jalil AMM. 2009. Antioxidant capacity and total phenolic content of Malaysian underutilized fruits. $J$. of Food Comp. and Anal. 22(5): 388-393.

Lenny S. 2006. Isolasi dan uji bioaktivitas kandungan kimia utama puding merah dengan metode uji brine shrimp. USU Repository, Medan.

Michael V, Perkins, William Kitching, Richard AI, Drew Christopher J, Moore Wilfried A König. 1990. Chemistry of fruit flies: composition of the male rectal gland secretions of some species of South-East Asian Dacinae. Re-examination of Dacus cucurbitae (melon fly). J. Chem. Soc., Perkin Trans. 1: 1111

Mori A, Nishino C, Enoki N, Tawata S. 1987. Antibacterial activivty and mode of action of plant flavonids againts Proteus vulgaris and Staphyloccus aureus. Phytochemistry 26: 2231-2234.

Over B. 2012. Natural product derived fragments for fragment-based ligand discovery. Nature Chemistry

Pelczar MJJr, Chan ECS. 1988. Dasar-Dasar Mikrobiologi. Volume ke-2. Hadioetomo RS, Imas T, Tjitrosomo SS, Angka SL, penerjemah. Jakarta: UI Pr. Terjemahan dari: Elements of Microbiology.

Prathipati P, Ma Nngai L and H Thomas. 2008. Global Bayesian Models for the Prioritization of Antitubercular Agents, $J$. Chem. Inf. Model. 48 (12): 2362-2370

Shinta. 2002. Isolasi dan Identifikasi Senyawa Aktif Anti Mikroba Dari Daun Tumbuhan Piper sarmentosum Roxb. Ex Hunter. Tesis, Universitas Indonesia.

Supratman U. 2010. Elusidasi Struktur Senyawa Organik. Bandung: Widya Padjadjaran.

Suradikusumah E. 2005. Spektroskopi I. Bogor: Fakultas Matematika dan Ilmu Pengetahuan Alam Institut Pertanian Bogor. 